\title{
Baicalin and Geniposide Inhibit Polarization and Inflammatory Injury of OGD/R-Treated Microglia by Suppressing the 5-LOX/LTB4 Pathway
}

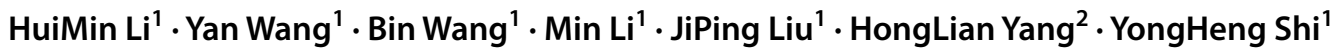

Received: 22 November 2020 / Revised: 25 February 2021 / Accepted: 17 March 2021 / Published online: 23 April 2021

(c) The Author(s) 2021

\begin{abstract}
Cerebral ischemia causes severe neurological disorders and neuronal dysfunction. Baicalin (BC), geniposide (GP), and their combination (BC/GP) have been shown to inhibit post-ischemic inflammatory injury by inhibiting the 5-LOX/CysLTs pathway. The aims of this study were to observe the inhibitory effects of BC/GP on the activation of microglial cells induced by oxygen glucose deprivation and reoxygenation (OGD/R) and to investigate whether the 5-LOX/LTB4 pathway was involved in these effects. Molecular docking showed that BC and GP exhibited considerable binding activity with LTB4 synthase LTA4H. BV-2 microglia were transfected with a 5-LOX overexpression lentiviral vector, and then OGD/R was performed. The effects of different concentrations of BC, GP, and BC/GP $(6.25 \mu \mathrm{M}, 12.5 \mu \mathrm{M}$, and $25 \mu \mathrm{M})$ on cell viability and apoptosis of microglia were evaluated by MTT and flow cytometry. The expression of TNF- $\alpha$, IL- $1 \beta$, NF- $\mathrm{kB}$, and pNF-kB also was measured by ELISA, Western blots and immunofluorescence. Western blots and qRT-PCR analysis were used to determine the levels of CD11b, CD206, and 5-LOX pathway proteins. Results showed that BC, GP, and BC/GP reduced the apoptosis caused by OGD/R in a dose-dependent manner, and cell viability was significantly increased at a concentration of $12.5 \mu \mathrm{M}$. OGD/R significantly increased the release of TNF- $\alpha, \mathrm{IL}-1 \beta, \mathrm{NF}-\kappa \mathrm{B}, \mathrm{pNF}-\mathrm{\kappa B}$, and CD11b. These effects were suppressed by $\mathrm{BC}$, GP, and $\mathrm{BC} / \mathrm{GP}$, and the OGD/R-induced transfer of NF- $\mathrm{kB}$ p65 from the ctytoplasm to the nucleus was inhibited in microglia. Interestingly, the LTB4 inhibitor, U75302, exhibited the same effect. Also, BC, GP, and BC/GP significantly reduced the expression of 5-LOX pathway proteins. These results demonstrated that BC/GP inhibited OGD/R-induced polarization in BV2 microglia by regulating the 5-LOX/LTB4 signaling pathways and attenuating the inflammatory response. Our results supported the theoretical basis for additional in-depth study of the function of BC/GP and the value of determining its unique target, which might provide a new therapeutic strategy for ischemic cerebrovascular disease.
\end{abstract}

Keywords Cerebral ischemic $\cdot$ Baicalin $\cdot$ Geniposide $\cdot$ Leukotriene B4 $\cdot$ Microglia $\cdot$ Inflammation

\section{Introduction}

Ischemic cerebral vascular disease (ICVD) involves acute occlusive lesions of blood vessels due to thromboembolism events that result in a decrease or interruption of the blood supply to specific regions of the brain. ICVD is a

Bin Wang

wangbin812@126.com

1 Key Laboratory of Pharmacodynamic Mechanism and Material Basis of Traditional Chinese Medicine, Shaanxi Provincial Administration of Traditional Chinese Medicine, Shaanxi University of Chinese Medicine, Xianyang 712046, China

2 Affiliated Hospital of Shaanxi University of Chinese Medicine, Xianyang 712046, China major cause of mortality and morbidity worldwide [1]. Ischemia can lead to a cascade of physiological and pathological reactions. The primary event is the activation of the inflammatory cascade that contributes to secondary processes, which ultimately result in brain injury [2-4]. Mounting evidence indicates that brain ischemia triggers inflammatory responses and leads to microglia activation, which produces a range of cytotoxic substances including TNF- $\alpha$, IL- $1 \beta$, iNOS, and other pro-inflammatory mediators that cause additional neuronal damage [5-7]. After ischemia, leukocytes infiltrate through the bloodbrain barrier (BBB) to the injured tissue and mediate the release of cytokines that further damage brain tissues [8]. Leukotriene B4 is produced from arachidonic acid (AA) through the sequential actions of 5-lipoxygenase (5-LOX), 5-lipoxygenase-activating protein (FLAP), and leukotriene 
A4 hydrolase (LTA4H) [9], and has a strong chemotactic effect on neutrophils and other leukocytes.

Huanglian jiedu decotion is a traditional Chinese medicine (TCM) compound composed of Rhizoma coptidis (huanglian), Radix scutellariae (huangqin), Cortex phellodendri (huangbo), and Fructus Gardeniae (zhizi). It is widely used for clearing heat dampness and to purge fire detoxification. Huanglian jiedu decotion has been used widely in the clinical treatment of a range of cardiovascular and cerebrovascular diseases. Huangqin and zhizi, which are traditional Asian herbs, also are used to clear heat dampness and purge fire detoxification. As the main active ingredient of huangqin, baicalin (BC), has been proven to have anti-bacterial and anti-inflammatory properties. It is widely used in the treatment of enteritis [10, 11], influenza [12-14], cerebrovascular diseases [15, 16]. $\mathrm{BC}$ has been shown to reduce cerebral infarct volume, and the pathological impairment of ischemic brain tissue has been alleviated in rats with cerebral ischemia, suggesting it has a neuroprotective effect on cerebral ischemia [17, 18]. Geniposide (GP), the main active ingredient of zhizi, elicits neuroprotective effects by alleviating inflammatory responses, and oxidative damage [19]. GP alleviates cognitive deficits by attenuating cholinergic defects and amyloidosis, as seen in a middle-aged Alzheimer model [20]. GP Geniposide treatment Perinatal hypoxic-ischemia mice significantly inhibited cell apoptosis, reduced serum IgG leakage into brain tissue, attenuated microgliosis, prevented loss of pericytes, loss of tight junction and adherens junction proteins[21]. GP in combination with ginsenoside $\operatorname{Rg} 1$ protected against focal cerebral ischemia in rats through inhibition of microglial microRNA following ischemic injury[22].

Our research team demonstrated that BC and GP in combination (BC/GP, 7:3) might ameliorate cerebral ischemic injury by inhibiting the 5-LOX/cysteinyl leukotrienes (CysLTs) pathway [23, 24]. It was proposed that inhibition of this pathway reduced inflammatory cell infiltration in ischemic areas through down-regulation of tumor necrosis factor- $\alpha$ (TNF- $\alpha$ ) and interleukin-beta (IL-1 $\beta)$, as well as up-regulating transforming growth factor-beta (TGF- $\beta$ ) and interleukin-10 (IL-10) [25]. However, it is unclear whether the protective effect of $\mathrm{BC} / \mathrm{GP}$ on cerebral ischemia occurs via 5-LOX/leukotriene B4 (LTB4).

In the present study, we hypothesized that the 5-LOX/ LTB4 pathway could be a therapeutic target for BC/GP (7:3) in cerebral ischemia-reperfusion injury. Therefore, network pharmacology and molecular docking were used to verify the protective mechanism of $\mathrm{BC}, \mathrm{GP}$, and $\mathrm{BC} / \mathrm{GP}$ on cerebral ischemic injury. We investigated whether the neuroprotective effects of BC/GP were accomplished by regulating the 5-LOX/LTB4 pathway and reduced production of pro-inflammatory factors in 5-LOX overexpressing microglia after oxygen glucose deprivation and reoxygenation $(\mathrm{OGD} / \mathrm{R})$.

\section{Materials and Methods}

\section{Data Acquisition}

All of the constituent data for huangqin and zhizi were obtained from the Traditional Chinese Medicine Systems Pharmacology Database and Analysis Platform (TCMSP, http://lsp.nwu.edu.cn/tcmsp.php) [26]. The bioactive ingredients of huangqin and zhizi were obtained from PubMed (http://www.ncbi.nlm.nih.gov/pubmed), CNKI (https:// www.cnki.net/), and Springer (https://link.springer.com/) databases. The active components and targets were further identified using the parameters of the oral bioavailability (OB) threshold that was greater than or equal to $20 \%$ and a drug likeness (DL) that was greater than or equal to 0.18 . FDA-approved targets for anti-cerebral ischemic injury drugs were collected from the Therapeutic Target Database (TTD) (http://bidd.nus.edu.sg/group/cjttd/), DrugBank (https://www.drugbank.ca/), Gene Cards (https://www. genecards.org/), and DisGeNET (http://www.disgenet.org/) databases. The targets obtained for huangqin and zhizi and the prediction targets for cerebral ischemia were mapped into Venny 2.1.0 (https://bioinfogp.cnb.csic.es/tools/venny/ index.html) to obtain the anti-ischemic targets for huangqin and zhizi.

To elucidate the pathways targeted by the compounds and any gene-associated diseases, the identified genes were further analyzed using Integrated Discovery (DAVID, https:// david.ncifcrf.gov/). A threshold count greater than or equal to 2 and EASE scores less than or equal to 0.05 were chosen for functional annotation clustering.

\section{Network Construction and Analysis}

The network was built using Cytoscape 3.4.0 software and the network analyzer plugin. After analyzing the compoundtarget and target-pathway networks, it was concluded that huangqin and zhizi had anti-cerebral ischemic injury effects.

\section{Molecular Docking}

The bioactive components of huangqin and zhizi were screened using Cytoscape analysis and Pubmed, CNKI, and Springer databases. The molecular structure was downloaded using TCMSP and PubChem (https://pubchem.ncbi. nlm.nih.gov/). The LTA4 hydrolase (LTA4H) protein structure was downloaded using the PDB (http://www.rcsb.org/ $\mathrm{pdb} /$ home/home.do) database. LTA4H was considered the synthase enzyme for LTB4. LTA4H was selected for docking 
since there was no protein conformation of LTB4 in the database. Protein preparation and subsequent molecular docking were performed using Discovery Studio 2.5 and Autodock Vina [27].

\section{Drugs and Reagents}

The sources for drugs and reagents used in the study included Human HEK293T and BV2 microglia (CTCC BIOSCIENCE), baicalin and geniposide (Solarbio Bio Inc. Beijing, China, content $\geq 98 \%$ ); dimethyl sulfoxide (DMSO, Sigma), MTT reagent (Sigma, USA), DMEM glucose medium (GIBCO BRL, USA), fetal bovine serum (FBS, GIBCO, USA), mouse TNF- $\alpha$ and IL-1 $\beta$ ELISA Kits (Tianjin sel biotechnology co. Ltd, China), Earle's liquid (GIBCO), SYBR Premix Ex Taq Kits (TaKaRa, Japan), as well as montelukast and U75302 (Chengdu huana chemical preparation co. Ltd, China).

\section{Synthesis of the pHBLV-CMV-MCS-3flag-EF1-puro/ Alox5 Plasmid}

The map of the pHBLV-CMV-MCS-3flag-EF1-puro plasmid vector is shown in Fig. 1a. The Alox5 sequence was directly synthesized into the pHBLV-CMV-MCS-3flag-EF1-puro vector. Figure $1 \mathrm{~b}$ demonstrates that the entire gene of the pHBLV-CMV-MCS-3flag-EF1-puro/Alox5 plasmid was synthesized successfully.

\section{BV2 Cell Virus Transfection}

293 T cells were cultured in DMEM basal culture medium with $10 \%$ FBS and $1 \%$ penicillin-streptomycin in an incubator at $37{ }^{\circ} \mathrm{C}$ and $5 \% \mathrm{CO}_{2}$. The $293 \mathrm{~T}$ cells were transfected with the phBL-CMV-MCS-3flag-EF1-PURo plasmid vector for lentivirus packaging. The supernatant was collected, and the virus particles were concentrated. BV2 microglia were incubated in $2 \mathrm{ml}$ antibiotic-free DMEM overnight. Then $1 \mathrm{ml}$ of the diluted viral mixture was added and the cells were incubated at $37{ }^{\circ} \mathrm{C}$ for $24 \mathrm{~h}$. The medium was changed to FBS/DMEM $24 \mathrm{~h}$ later. The lowest cell lethal concentration was screened by adding the drug, G418. The drug concentration gradient was set at $200 \mu \mathrm{g} / \mathrm{ml}, 300 \mu \mathrm{g} /$ $\mathrm{ml}, 400 \mu \mathrm{g} / \mathrm{ml}$, and $500 \mu \mathrm{g} / \mathrm{ml}$. Between the third day and the eighth day after adding G418, numerous cells began to die. The surviving cells formed monoclonal cultures, which were cultured further.

\section{Cell Culture and Treatment}

BV2 microglia were transfected with the 5-LOX virus and cultured in medium with $10 \% \mathrm{FBS}, 1 \%$ penicillin-streptomycin in an incubator at $37{ }^{\circ} \mathrm{C}$ and $5 \% \mathrm{CO}_{2}$. When the $\mathrm{BV} 2$ cells had been passaged to the third generation, the culture medium was changed to a sugar-free Earle's solution. Cells were pretreated with various concentrations of $\mathrm{BC}, \mathrm{GP}, \mathrm{BC} /$ GP (7:3), U75302 (5 $\mu \mathrm{M})$, and montelukast $(5 \mu \mathrm{M})$ for $4 \mathrm{~h}$. Subsequently, OGD/R (oxygen-glucose deprivation for $2 \mathrm{~h}$ and reperfusion for $12 \mathrm{~h}$ ) was carried out at $37^{\circ} \mathrm{C}$ using a three-gas incubator (94\% nitrogen, 5\% carbon dioxide, and $1 \%$ oxygen).

\section{Cell Viability Analysis}

Cells were added to a 96-well plate at a concentration of 5000 cells/well. The MTT solution $(5 \mathrm{mg} / \mathrm{mL}$, Sigma) was added to the culture medium after stimulation. The cells were kept in a humidified incubator with $95 \%$ air and 5\% $\mathrm{CO}_{2}$ at $37{ }^{\circ} \mathrm{C}$ for $4 \mathrm{~h}$. The absorbance at $570 \mathrm{~nm}$ was measured using a microplate reader. The experimental groups are listed in Table 1.
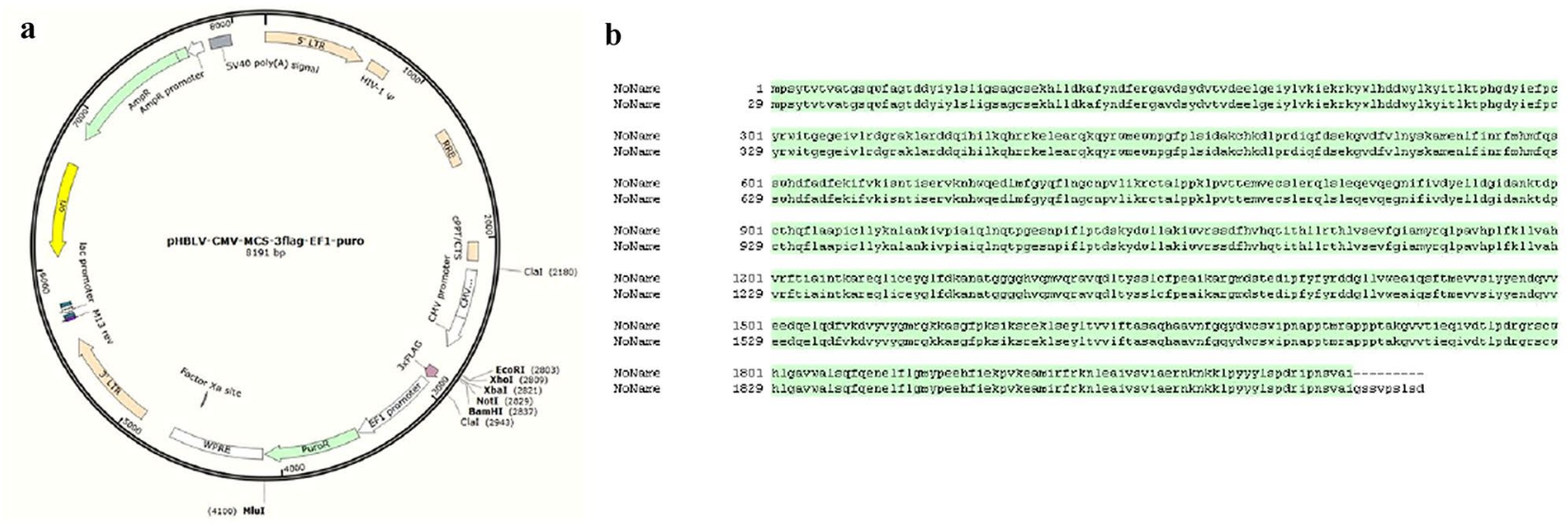

Fig. 1 a pHBLV-CMV-MCS-3flag-EF1-puro/Alox 5 plasmid; b comparison of Alox 5 sequencing results 
Table 1 Experimental groups and drug doses

\begin{tabular}{|c|c|}
\hline Groups & Drug administration \\
\hline Control group & BV2 cells (virus-free), no OGD/R \\
\hline OGD/R group & BV2 cells (virus-free), OGD/R \\
\hline Model group & $\mathrm{BV} 2$ cells +5 -LOX virus, OGD/R \\
\hline \multirow[t]{9}{*}{ Drug groups } & $\mathrm{BV} 2$ cells +5 -LOX virus $+\mathrm{BC}(6.25 \mu \mathrm{M}), \mathrm{OGD} / \mathrm{R}$ \\
\hline & $\mathrm{BV} 2$ cells +5 -LOX virus $+\mathrm{BC}(12.5 \mu \mathrm{M}), \mathrm{OGD} / \mathrm{R}$ \\
\hline & $\mathrm{BV} 2$ cells +5 -LOX virus $+\mathrm{BC}(25 \mu \mathrm{M}), \mathrm{OGD} / \mathrm{R}$ \\
\hline & $\mathrm{BV} 2$ cells +5 -LOX virus $+\mathrm{GP}(6.25 \mu \mathrm{M}), \mathrm{OGD} / \mathrm{R}$ \\
\hline & $\mathrm{BV} 2$ cells +5 -LOX virus $+\mathrm{GP}(12.5 \mu \mathrm{M}), \mathrm{OGD} / \mathrm{R}$ \\
\hline & $\mathrm{BV} 2$ cells $+5-\mathrm{LOX}$ virus $+\mathrm{GP}(25 \mu \mathrm{M}), \mathrm{OGD} / \mathrm{R}$ \\
\hline & $\begin{array}{l}\text { BV2 cells + 5-LOX virus + BC/GP }(6.25 \mu \mathrm{M}) \text {, } \\
\text { OGD/R }\end{array}$ \\
\hline & $\begin{array}{l}\text { BV2 cells }+5 \text {-LOX virus + BC/GP }(12.5 \mu \mathrm{M}) \text {, } \\
\text { OGD/R }\end{array}$ \\
\hline & $\mathrm{BV} 2$ cells +5 -LOX virus $+\mathrm{BC} / \mathrm{GP}(25 \mu \mathrm{M}), \mathrm{OGD} / \mathrm{R}$ \\
\hline
\end{tabular}

\section{Apoptosis Assay}

The cells were stained with propidium iodide (PI) and fluorescein isothiocyanate (FITC)-conjugated Annexin V stain (BD Bioscience, USA) to analyze cell apoptosis. The cells were washed three times using phosphate-buffered saline (PBS), then stained with PI in the dark at room temperature for $20 \mathrm{~min}$. The cells were analyzed for cell cycle stages using a Canto II flow cytometer (BD Bioscience, USA). The cell groups that were assessed are shown in Table 1.

\section{Enzyme-Linked Immunosorbent Assay (ELISA)}

After BV2 microglia were transfected with the 5-LOX virus, the cells were treated with OGD/R in 24-well plates. The supernatant was collected. The concentrations of inflammatory factors, TNF- $\alpha$ and IL- $1 \beta$, were determined using ELISA kits according to the manufacturer's instructions. The assays were standardized based on cell protein concentrations. The experimental groups and drug concentrations that were used are shown in Table 2.

\section{RT-PCR}

RNA was extracted from BV2 cells using Trizol reagent (Invitrogen, Waltham, MA, USA). The total RNA was isolated using a reverse transcription kit according to the manufacturer's instructions. The first-strand cDNA was prepared from the total RNA $(1 \mu \mathrm{g})$ using reverse transcription (RT). The cDNA was amplified using SYBR Premix Ex Taq (Takara, Japan) with specific primers. The primer sequences for the specific genes are shown in Table 3.

\section{Western Blots}

Proteins were extracted using RIPA lysis buffer. Protein quantification was measured using a BCA Protein Assay Kit (Tianjin sel biotechnology co. Ltd) according to the manufacturer's instructions. The proteins $(10 \mu \mathrm{g})$ were separated on a $10 \%$ SDS-polyacrylamide (PAGE) gel and transferred to a polyvinylidene difluoride (PVDF) membrane. The membrane was blocked with 5\% skim milk for $1 \mathrm{~h}$, washed three
Table 2 Experimental groups and drug concentrations

\begin{tabular}{ll}
\hline Groups & Drug administration \\
\hline Control group & BV2 cells (virus-free), no OGD/R \\
OGD/R group & BV2 cells (virus-free), OGD/R \\
Model groups & BV2 cells + 5-LOX virus, OGD/R \\
Positive drug groups & BV2 cells + 5-LOX virus + Montelukast, OGD/R \\
Drug groups & BV2 cells + 5-LOX virus + U75302, OGD/R \\
& BV2 cells + 5-LOX virus + BC $(12.5 \mu \mathrm{M})$, OGD/R \\
& BV2 cells + 5-LOX virus + GP $(12.5 \mu \mathrm{M}), \mathrm{OGD/R}$ \\
& BV2 cells + 5-LOX virus + BC/GP $(12.5 \mu \mathrm{M}), \mathrm{OGD} / \mathrm{R}$ \\
\hline
\end{tabular}

\begin{tabular}{lll}
\hline Gene & Forward $\left(5^{\prime} \rightarrow 3^{\prime}\right)$ & Reverse $\left(3^{\prime} \rightarrow 5^{\prime}\right)$ \\
\hline Alox5-S & CTTTATTCTATTTATGCT & TTGGTGGGGGTGGGAGT \\
LTB4 & AGGAGCCACTTCTCTGGTGA & GCAGCTTCTGAAACCCAGTC \\
CD206 & ATACCTTTGATGAATACA & GTCCTGAAAATACCCTGAGTGG \\
CysLTs & CTTGAACGTACTCTGACACTACAA & GAGATGTCGTCAGATTTTCAGTCCAT \\
CD11b & CATCCCATCTTTCCCGCTAATTCTG & TCGGTCCTGGACACGTTGTTCTCA \\
$\beta$-actin & CATGTACGTTGCTATCCAGG & CTCCTTAATGTCACGCACGAT \\
\hline
\end{tabular}

Table 3 RT-PCR primer sequences 
times (5 min each) with Tris-buffered saline plus Tween-20 (TBST). Each membrane was incubated with its respective primary antibody at $4{ }^{\circ} \mathrm{C}$ overnight, washed in TBST three times (8 min each) and incubated with secondary antibody for $2 \mathrm{~h}$ at room temperature, then washed again in TBST three times ( $8 \mathrm{~min}$ each). The protein bands were detected using electrochemiluminescence (ECL), and the band density was normalized using $\beta$-actin.

\section{Immunofluorescence Analysis}

To determine the expression and localization of NF- $\mathrm{kB}$ p 65 in the BV2 cells, double-labeled immunocytochemistry was performed according to a previously described protocol [7, 28].

\section{Statistical Analyses}

All statistical analyses were performed using Graphpad Prism 5 software. Data were expressed as means \pm SD from at least three independent experiments. The comparison of the same time points was performed by independent sample t-tests or analysis of variance. One-way analysis of variance was used and the data between the two groups were compared using the LSD test. $\mathrm{P}<0.05$ and $\mathrm{P}<0.01$ were considered statistically significant.

\section{Results}

\section{Network Pharmacology Identified that Huangqin and Zhizi Might have Anti-inflammatory Effects on Cerebral Ischemia}

Sixty-two chemical constituents were identified for huangqin, and 32 chemical constituents were identified for zhizi. Two hundred fifty-seven predicted targets were screened from TCMSP, TCMID, and other databases. The targets obtained for huangqin and, zhizi and the prediction targets for cerebral ischemia were mapped into Venny to obtain 193 anti-ischemic targets for huangqin and zhizi (Fig. 2a). The drug-target interaction networks (Fig. 2b) were visualized using Cytoscape. Thus, it was determined that baicalin (BC) and geniposide (GP) were the main components involved in anti-cerebral ischemia.

The 193 anti-ischemic targets were associated with the following five functions, response to hypoxia, apoptosis, cell proliferation, inflammatory responses, and angiogenesis (Fig. 3a). KEGG (Fig. 3b) analysis revealed that these target proteins were involved in multiple signaling pathways. The identified pathways could be divided into four broad categories, including (1) cell proliferation and differentiation, (2) regulation of adhesion, aggregation, and migration of immune cells, (3) inflammatory factors and inflammatory mediators that directly mediated the regulation of cerebral ischemia inflammation, (4) regulation of receptors that mediated the expression of downstream inflammatory factors.

Through the analysis of GO-BP and KEGG, we determined that the anti-ischemic injury targets of huangqin and zhizi primarily acted on the inflammatory response. 5-LOX, CysLTs and LTB4, which are metabolites of arachidonic acid, were the common inflammatory targets of BC and GP. Based on our research team's previous research, we carried out a follow-up study on the effects of BC and GP on LTB4.

\section{BC and GP Showed Good Binding Activity to LTA4H, a LTB4 Synthase}

The network topology was analyzed using the network analysis plugin. The components that were greater than the average value of Degree and BC were selected as the primary components of huangqin and zhizi that were active against cerebral ischemia. When the effects of the components in huangqin and zhizi on cerebral ischemia, the active a

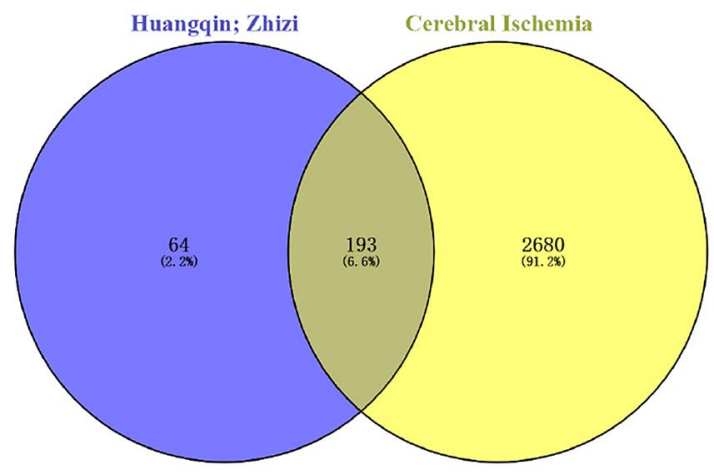

b

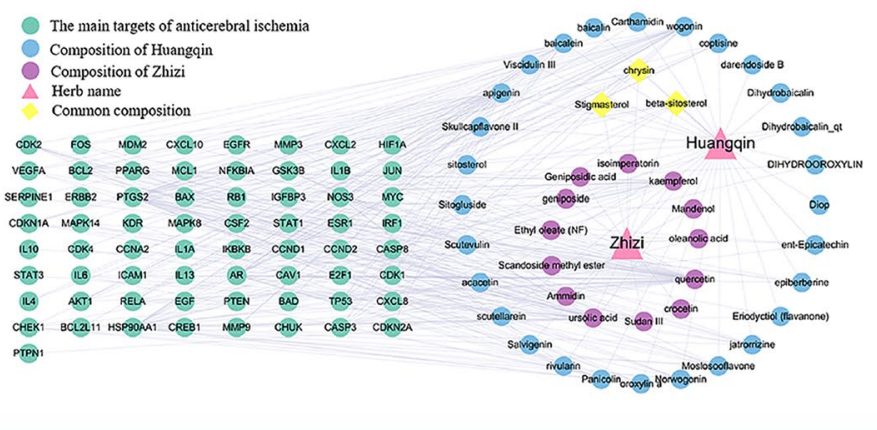

Fig. 2 Network maps. a Mapping of huanglian, zhizi and cerebral ischemia targets. b Drug-target interaction network 

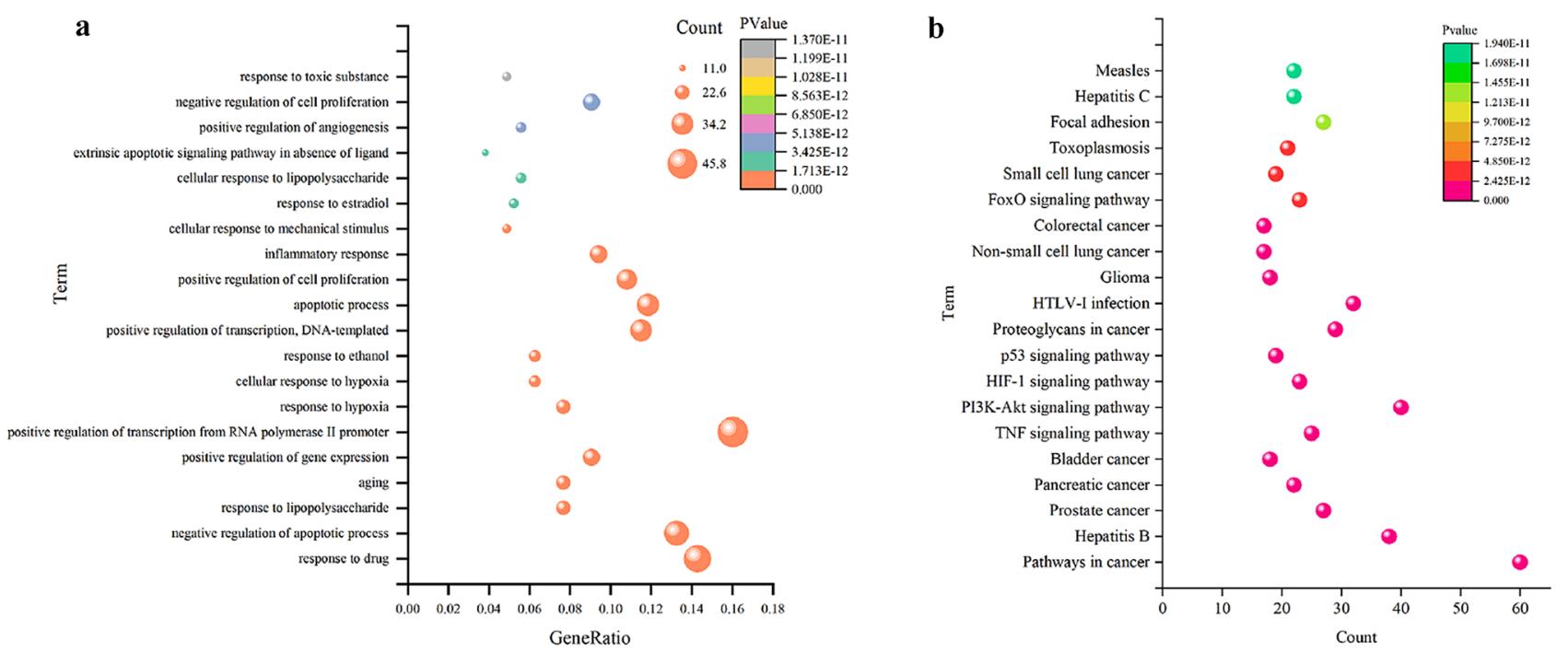

Fig. 3 Enrichment analysis. a GO enrichment analysis; b KEGG enrichment analysis

Table 4 Docking parameters

\begin{tabular}{llll}
\hline Molecular & CAS & Protein & $\begin{array}{l}\text { Affinity } \\
(\mathrm{kcal} / \\
\mathrm{mol})\end{array}$ \\
\hline U75302 & $119477-85-9$ & LTA4H (4MKT) & -8.1 \\
Baicalein & $491-67-8$ & & -8.9 \\
Baicalin & $21967-41-9$ & & -9.2 \\
Geniposide & $24512-63-8$ & & -7.5 \\
\hline
\end{tabular}

components with higher concentrations in huangqin and zhizi were selected as docking molecules using the CNKI, PubMed, Springer databases. The antagonist for leukotriene B4, U75302, was selected as a reference. The parameter settings and docking results are shown in Table 4. Prediction of the binding activity with LTA4H for the compounds was based on the binding energy in $\mathrm{kcal} / \mathrm{mo}$. Binding energy that was greater than 7.0 indicated strong binding activity [29]. Molecular docking showed that the active ingredients in huangqin and zhizi had strong binding efficiency with LTA4H, and the conformations for baicalin and geniposide were plotted (Figs. 4, 5). We predicted that baicalin and geniposide (BC/GP) could inhibit LTB4.

\section{BC/GP Reduced Apoptosis, and 12.5 $\mu \mathrm{M} \mathrm{BC/GP}$ Improved Cell Viability in BV2 Microglia Cells Exposed to OGD/R}

After BV2 microglia were transfected with the 5-LOX virus and exposed to the OGD/R environment, we observed that the rate of apoptosis in microglia was significantly higher than the control and OGD/R only groups $(p<0.01$, Fig. 6a, b). After treatment with different concentrations of BC, GP, and BC/GP (7:3), the rate of apoptosis was significantly reduced in a dose-dependent manner $(p<0.01$, Fig. 6b). When the microglia that overexpressed 5-LOX were exposed to OGD/R, the microglia exhibited significantly lower cell viability than the control group ( $p<0.01$, Fig. 6a). At concentrations of $6.25 \mu \mathrm{M}, 12.5 \mu \mathrm{M}$, and $25 \mu \mathrm{M}, \mathrm{BC}, \mathrm{GP}$, and BC/GP (7:3) significantly increased cell viability compared with the model ( $p<0.01$, Fig. 6a). The data revealed that the cell viability was optimal when the concentrations of $\mathrm{BC}$, GP, and BC/GP (7:3) were $12.5 \mu \mathrm{M}$. The results also revealed a significant difference between with $6.25 \mu \mathrm{M}$ and $25 \mu \mathrm{M}$ concentrations ( $p<0.01$, Fig. 6a). Thus, the concentration of $12.5 \mu \mathrm{M}$ was used in later experiments.

\section{BC/GP Relieved OGD/R-Induced Inflammatory Damage in BV2 Microglia}

When the microglia overexpressing 5-LOX were exposed to OGD/R, the levels of TNF- $\alpha$ (Fig. 7a) and IL-1 $\beta$ (Fig. 7b) released from the cells were significantly higher than in the control group $(p<0.01)$. However, BC, GP, and BC/GP (7:3) inhibited this increase ( $p<0.01$, Fig. 7$)$. The combination of $\mathrm{BC} / \mathrm{GP}$ had the greatest efficacy, and there was a significant difference when the effects of BC/GP were compared with the BC and GP groups ( $p<0.01$, Fig. 7). The effect of the LTB4 antagonist, U75032, was stronger than montelukast, a CysLTs antagonist $(p<0.01$, Fig. 7$)$. These data indicated that BC/GP and U75302 could alleviate OGD/R-induced inflammatory damage in BV2 microglia.

Activation of NF- $\mathrm{BB}$ is a central event leading to inflammation, which is characterized by the translocation of p65 from the cytoplasm to the nucleus and the expression of 

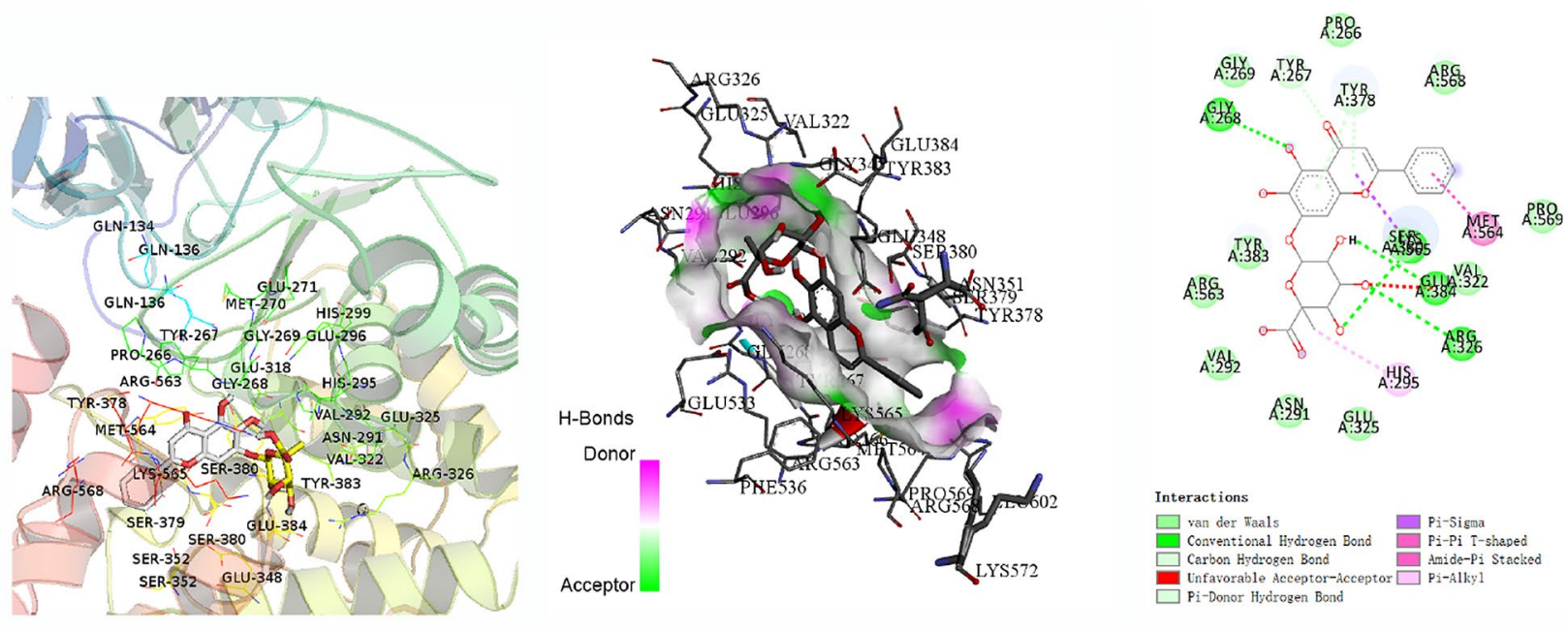

Fig. 4 Schematic diagram of the optimal conformation and interaction between baicalin and LTA4H
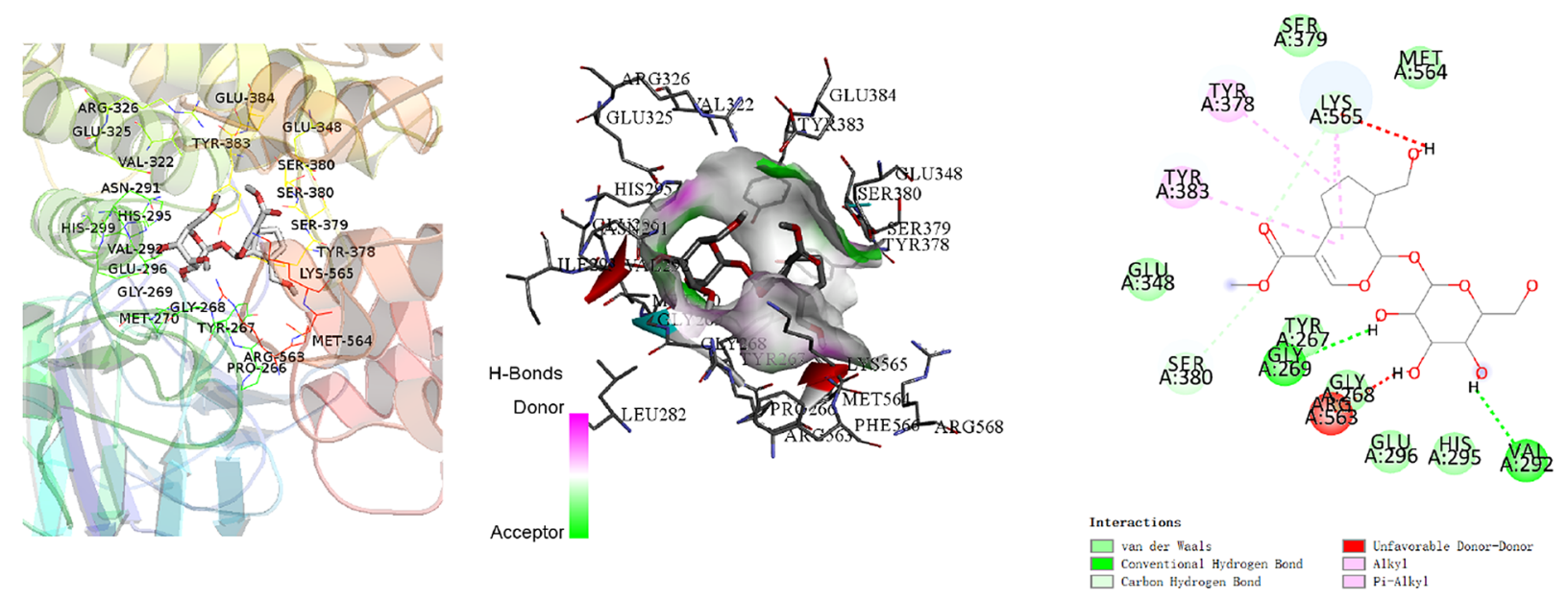

Fig. 5 Schematic diagram of the optimal conformation and interaction between geniposide and LTA4H

phosphorylated p65. The Western blot analysis indicated that when microglia overexpressing 5-LOX were exposed to OGD/R, the expression level of phosphorylated NF- $\mathrm{kB}$ p65 was significantly higher than the control and OGD/R groups ( $p<0.01$, Fig. 8a). NF-кB p65 phosphorylation levels were significantly reduced after treatment with $\mathrm{BC}$,

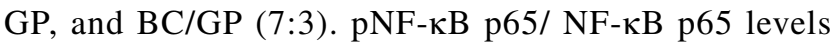
were significantly lower than that of the $\mathrm{BC}$ and GP groups after BC/GP treatment ( $p<0.01$, Fig. 8a), indicating the efficacy of BC/GP was superior to that of BC and GP. The phosphorylation level of NF- $\mathrm{KB}$ p65 after U75302 treatment was significantly lower than that of the montelukast group ( $p<0.01$, Fig. 8a).
We also examined the localization of NF- $\mathrm{BB}$ p65 in BV2 cells in different conditions using double-labeled immunofluoresce. As shown in Fig. 8b, NF-кB p65 was expressed primarily in the cytoplasm (green) in the control group. However, it was translocated to the nucleus in the model group (Fig. 8). Merged images (blue/green) indicated that OGD/R induced much of the NF- $\mathrm{KB}$ p65 protein transfer from the cytoplasm to the nucleus. Treatment with $12.5 \mu \mathrm{M}$ $\mathrm{BC}, \mathrm{GP}$, and BC/GP (7:3) markedly reversed NF- $\mathrm{B}$ p65 immunostaining to nearly basal levels and redistributed it into the nucleus and cytoplasm. BC/GP (7:3) at the concentration of $12.5 \mu \mathrm{M}$ exerted a much more robust inhibitory effect. 


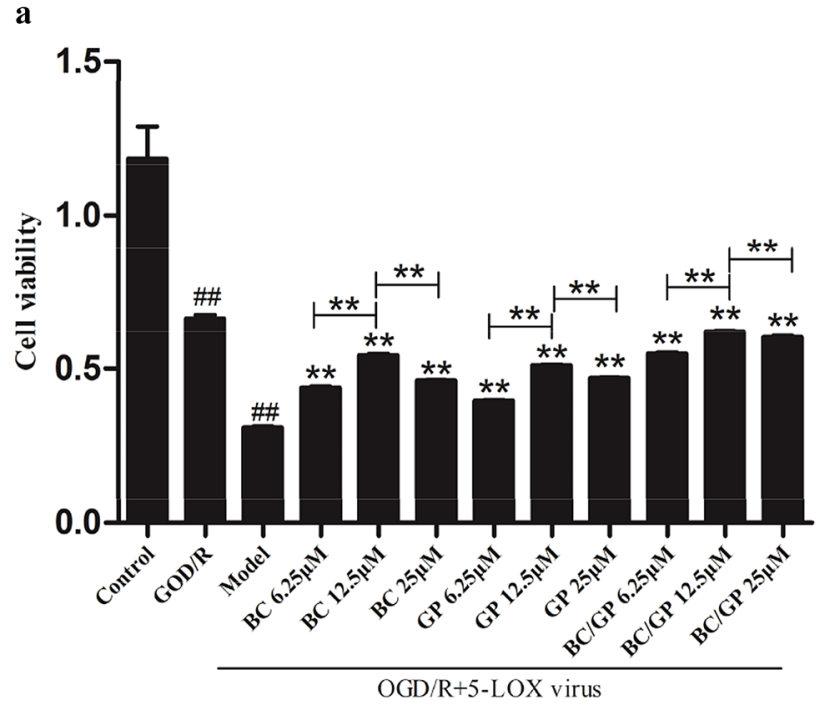

Fig. 6 Effects of different concentrations of BC, GP and BC/GP (7:3) on cell viability and apoptosis. a MTT was used to detect cell activity. b Apoptosis was detected using flow cytometry. Each value indi- b

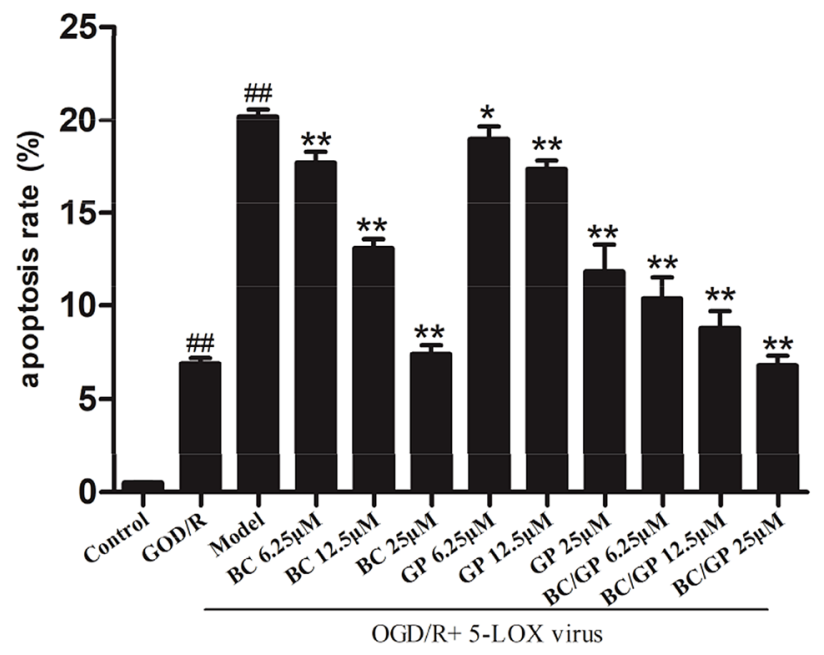

cates the mean $\pm \mathrm{SD}(\mathrm{n}=6) .{ }^{\# \#} p<0.01$ compared to the control group, $* * p<0.01$ compared to the model group

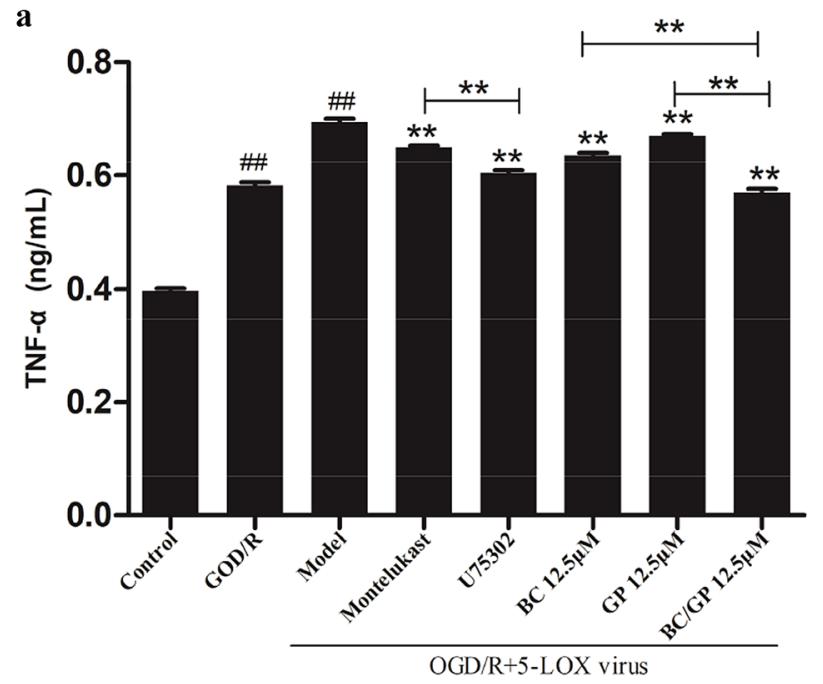

Fig. 7 BC/GP relieved OGD/R induced inflammatory damage. U75302 is an antagonist of LTB4. Montelukast is an antagonist of CysLTs. a The concentration of TNF- $\alpha$ was tested using an ELISA.

\section{BC/GP Inhibited the Expression of M1 and M2 Markers in Microglia}

To evaluate whether the neuroprotective effect of BC/GP (7:3) was associated with BV2 microglia polarization, we measured the expression of CD11b and CD206 using qRTPCR and Western blots to determine the effect of BC/GP (7:3) on phenotype switches of the microglia. The qRT-PCR and Western blot analysis (Fig. 9a, b) revealed that when

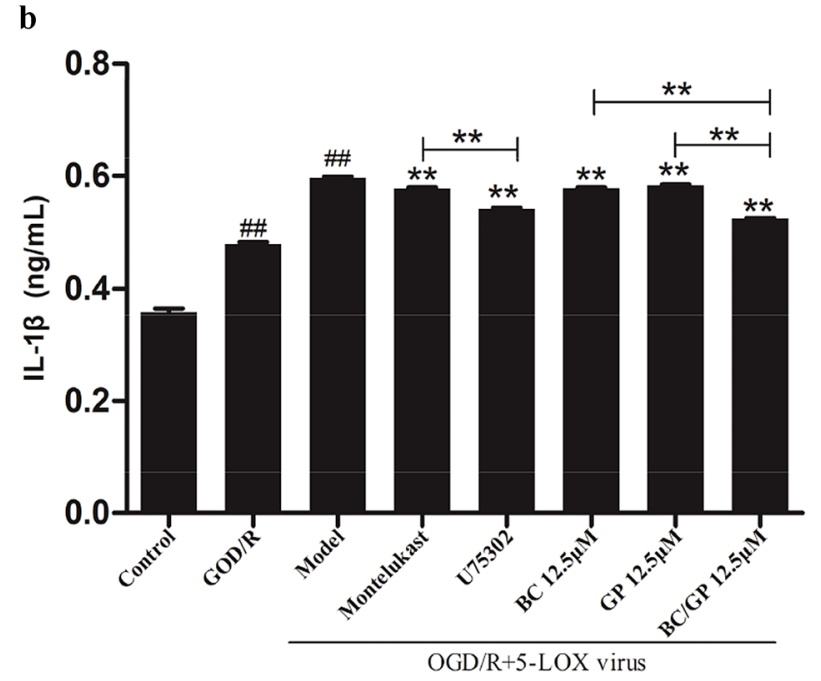

b The concentration of IL- $1 \beta$ was tested using an ELISA. Each value indicates the mean $\pm \mathrm{SD}(\mathrm{n}=3)$. ${ }^{\# \#} \mathrm{p}<0.01$ compared to the control group, $* * \mathrm{p}<0.01$ compared to the model group

microglia overexpressing 5-LOX were exposed to OGD/R, the expression of the M1 marker, CD11b, was significantly higher than the control group $(p<0.01)$. After treatment with $\mathrm{BC}, \mathrm{GP}$, and BC/GP, the expression of $\mathrm{CD} 11 \mathrm{~b}$ was significantly lower than the model group. Compared with the $\mathrm{BC}$ and GP groups, the combination of $\mathrm{BC} / \mathrm{GP}$ had the greatest effect and produced synergistic effects $(p<0.01)$. Compared with montelukast, the CD11b mRNA levels were significantly reduced after U75302 treatment ( $p<0.01$, Fig. 9b), 
a
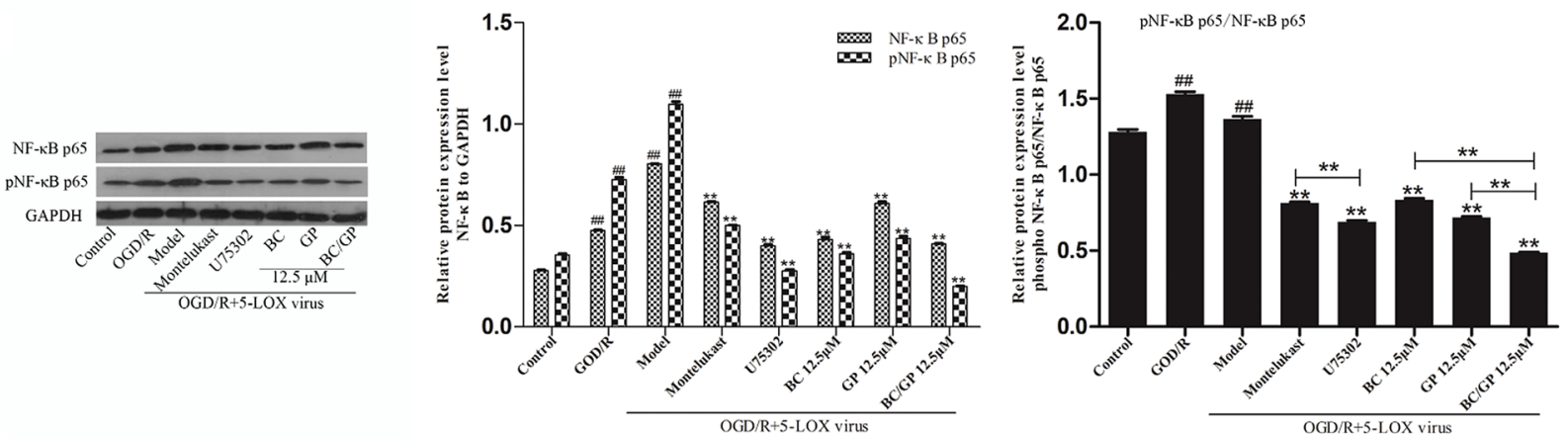

b
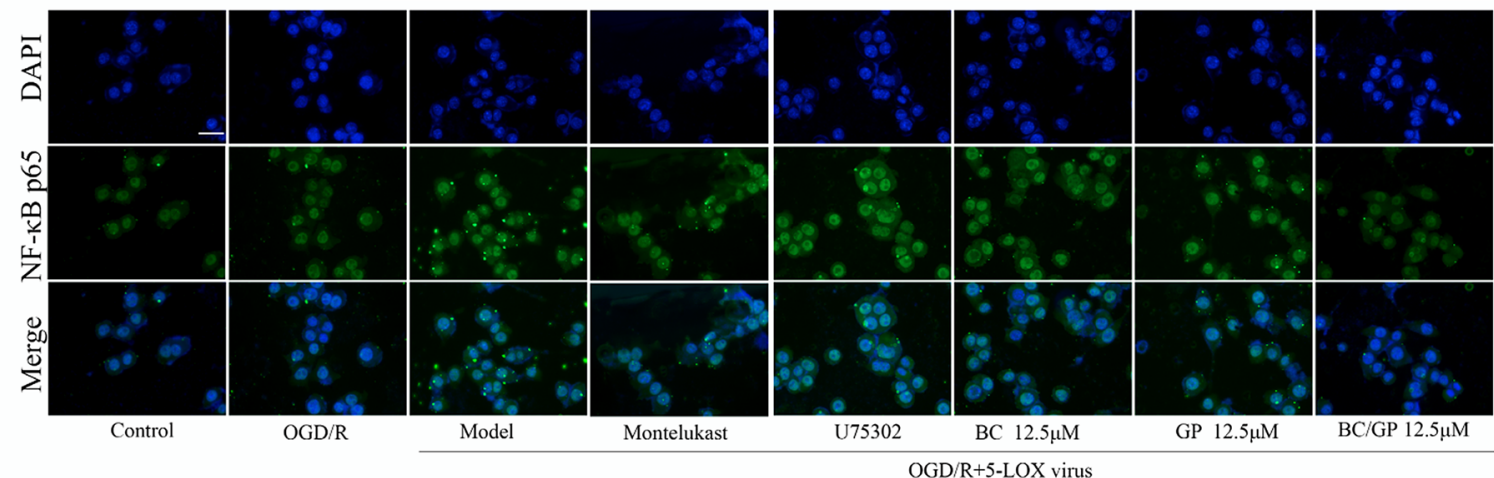

$\mathrm{OGD} / \mathrm{R}+5$-LOX virus

Fig. 8 BC/GP inhibited NF- $\kappa B$ activation. U75302 is an antagonist of LTB4. Montelukast is an antagonist of CysLTs. a Protein levels of NF- $\kappa \mathrm{B}$ p 65 and pNF- $\kappa \mathrm{B}$ p65 were analyzed using Western blots. b The cellular location of NF- $\mathrm{BB}$ p65 in 5-LOX overexpressing micro-

but protein levels were increased based on the Western blot results ( $p<0.01$, Fig. 9a). We also observed that the expression of the microglia M2 marker, CD206, exhibited the same trend as CD11b (Fig. 9a, b). When microglia overexpressing 5-LOX were exposed to OGD/R, the expression of CD206 was significantly higher than the control and OGD/R groups ( $p<0.01$, Fig. 9a, b). After treatment with BC, GP and BC/GP, CD11b expression was significantly lower than the model group. The effect of BC/GP were more robust than BC and GP ( $\mathrm{p}<0.01)$. U75302 and Montelukast significantly reduced the expression of CD206 compared with the model group $(\mathrm{p}<0.01)$. These results demonstrated that LTB4 regulated microglia polarization.

\section{BC/GP Exhibited an Inhibitory Effect on the 5-LOX Pathway}

To further clarify the role of BC/GP, we assessed the expression of 5-LOX pathway proteins using Western blots and qRT-PCR. The Western blots and qRT-PCR results showed that when microglia overexpressing 5-LOX were exposed to OGD/R, the expression of 5-LOX was significantly increased compared with the control group $(p<0.01$, glia exposed to OGD/R. Scale bar $=20 \mu \mathrm{m}$. Each value indicates the mean $\pm \mathrm{SD}(\mathrm{n}=3) .{ }^{\# \#} \mathrm{p}<0.01$ compared to the control group, $* * \mathrm{p}<0.01$ compared to the model group

Fig. 10a, b). After treatment with BC, GP, and BC/GP, the expression of 5-LOX was significantly lower than the model group. Compared with BC and GP groups, the combination of BC/GP (7:3) had the greatest effect and produced synergistic effects ( $p<0.01$, Fig. 10a, b). Compared with montelukast group, the U75302 group displayed significantly reduced expression of 5-LOX ( $p<0.01$, Fig. 10a, b). This suggests that the LTB4 pathway might play a dominant role in the elevated expression of 5-LOX.

Based on the qRT-PCR results, we determined that the expression of CysLTs and LTB4 mRNAs was significantly higher in the model group than the control and OGD/R groups ( $p<0.01$, Fig. 10b). Western blot results showed that the expression of CysLT1, CysLT2, BLT1, BLT2, and the LTB4 synthetase, LTA4H, were significantly higher in the model group than the control and OGD/R groups $(p<0.01$, Fig. 10a). After treatment with BC, GP, and BC/GP, the expression of CysLTs mRNA, LTB4 mRNA, CysLT1, CysLT2, BLT1, BLT2, and LTA4H were significantly lower than the model group ( $p<0.01$, Fig. 10a, b). Compared with the $\mathrm{BC}$ and GP groups, the combination of BC/GP (7:3) had the greatest effect and produced synergistic effects $(\mathrm{p}<0.01$, Fig. 10a, b). This result indicated that BC/GP (7:3) might 
a
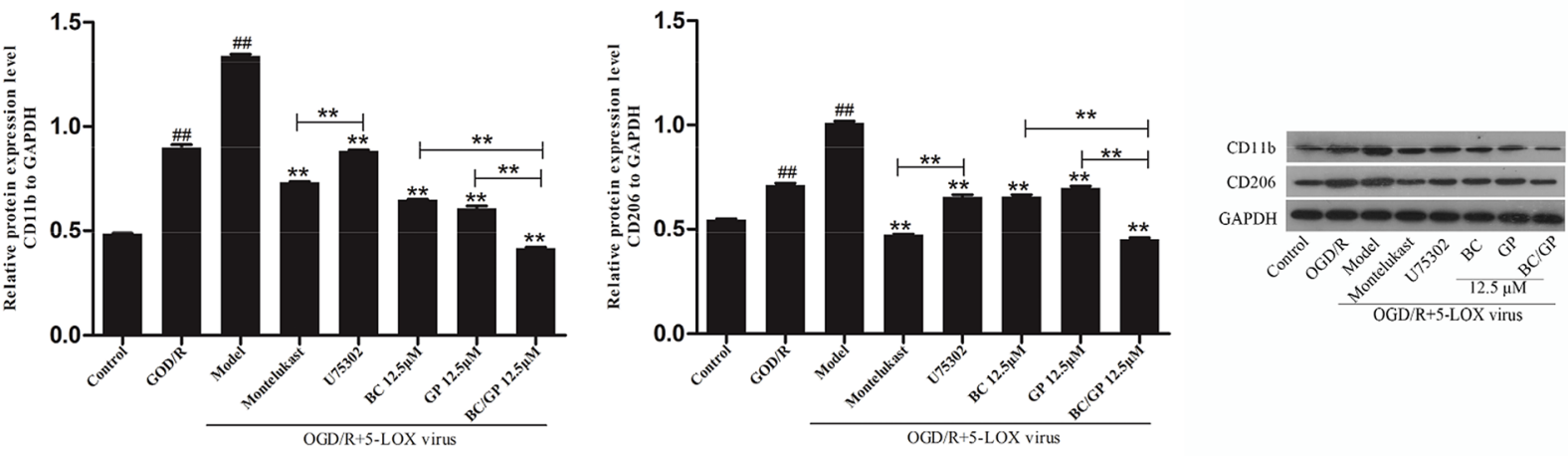

b
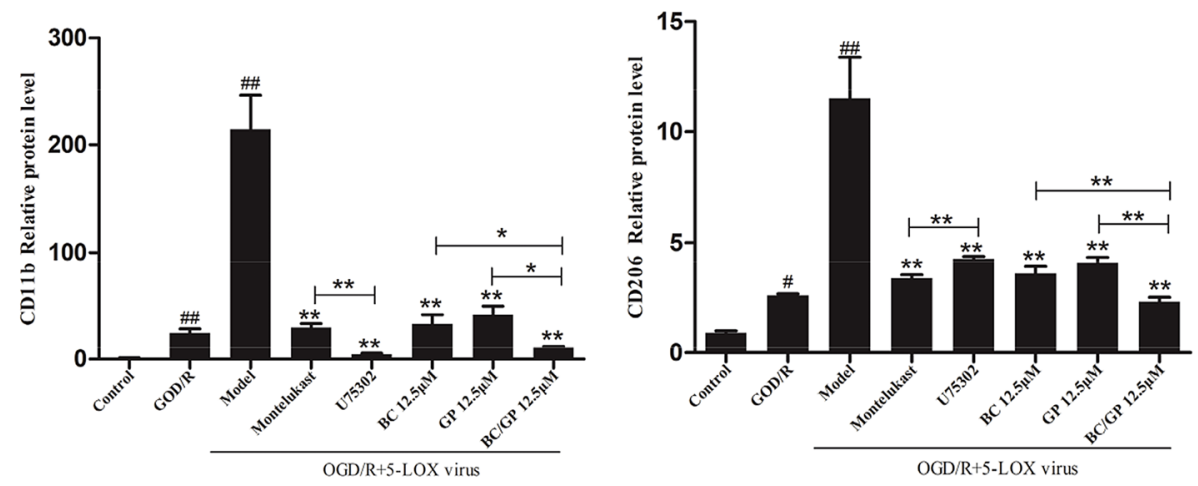

Fig. $9 \mathrm{BC} / \mathrm{GP}$ inhibited microglial polarization. CD11b is a microglial M1 marker. CD206 is a microglial M2 marker. U75302 is an antagonist of LTB4. Montelukast is an antagonist of CysLTs. a Protein levels of CD11b and CD206 were analyzed using Western blots.

protect microglia from OGD/R damage by down-regulating the 5-LOX pathway. The effect of the combination of BC and GP was superior to BC and GP alone, and it exhibited a synergistic effect.

\section{Discussion}

During cerebral ischemia, numerous inflammatory factors are produced that induce secondary injury and lead to neuronal damage. It has been reported that baicalin (BC) and geniposide (GP) exert protective effect on PC12 cells injured by OGD [30, 31]. Studies also have shown that baicalin prevented OGD-induced apoptosis of SH-SY5Y cells in culture and hippocampal cells, resulting in improved learning and memory impairment induced by global cerebral ischemia/ reperfusion in gerbils [32]. Our reaserch team found earlier that $\mathrm{BC}$ and GP in combination (BC/GP) protected neurological function from injury, improved BBB permeability, and alleviated brain edema injury in a rat model of ischemia-reperfusion [33-35]. Our team also found that $\mathrm{BC}, \mathrm{GP}$, and $\mathrm{BC} / \mathrm{GP}$ reduce inflammatory injury and tissue edema in the ischemic area of rats with cerebral ischemia b Expression of CD11b and CD206 was assessed using through qRTPCR. Each value indicates the mean $\pm S D(n=3)$. ${ }^{\#} p<0.01$ compared to the control group, ${ }^{*} \mathrm{p}<0.01$ compared to the model group

$[25,36]$. The underlying mechanism is related to the inhibition of microglia activation and the 5-LOX/CysLTs signal pathway [23]. Based on the search of the CNKI, PubMed, and Springer databases, we discovered that BC and GP were the active components of huangqin and zhizi. For the first time, we conducted a network pharmacologic analysis of huangqin and zhizi to determine the mechanism of action of $\mathrm{BC}$ and GP involved in the treatment of cerebral ischemia. We predicted that huangqin and zhizi protected against cerebral ischemic injury primarily through inhibiting inflammation. The results of the network pharmacology prediction were consistent with our previous study.

Increasing evidence has confirmed the ubiquitous role of neuroinflammation in the pathogenesis of neurological disorders, including Alzheimer's disease (AD), Parkinson's disease (PD), and ischemic stroke [37-39]. Microglia are intrinsic components of the brain immune system [40] and are activated in response to brain injury [41]. It is well known that activated microglia become hypertrophic, undergo rapid proliferation, and migrate to inflammatory sites where they produce excessive amounts of neurotoxic and pro-inflammatory mediators that produce neuronal damage [42-44]. On the other hand, apart from microglia, other 
a
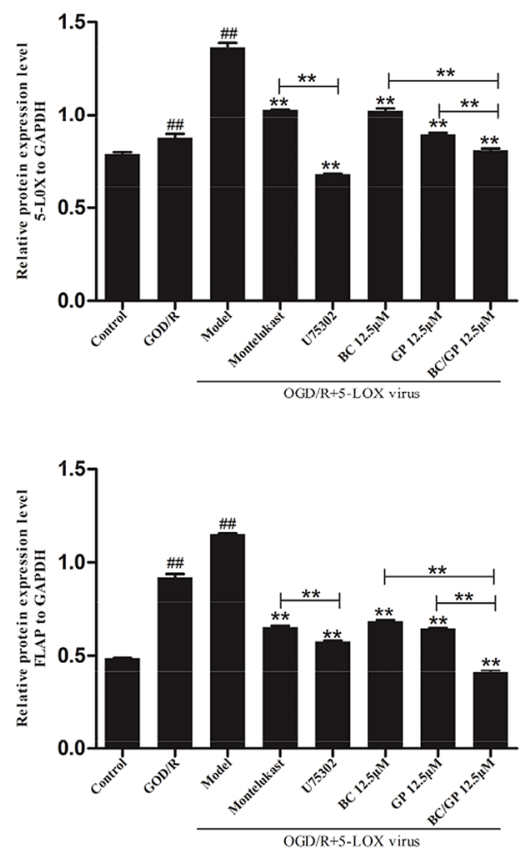

b

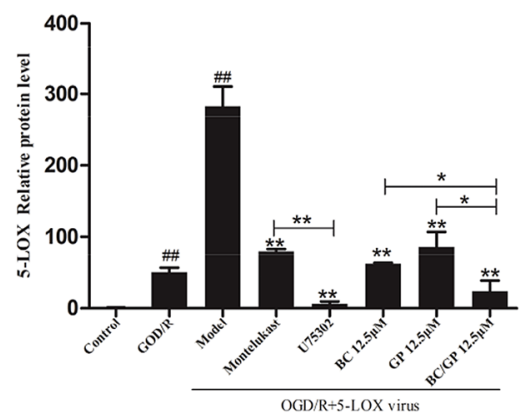

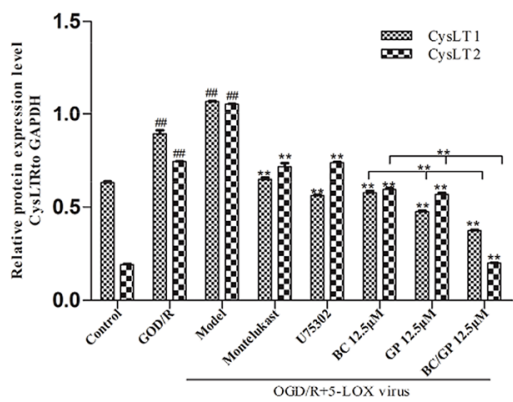

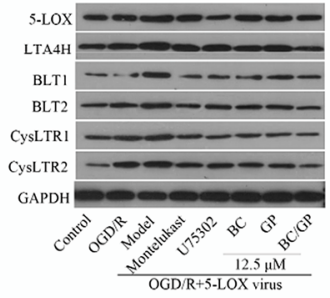

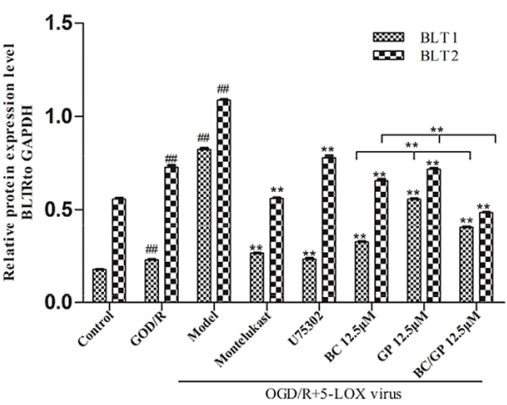
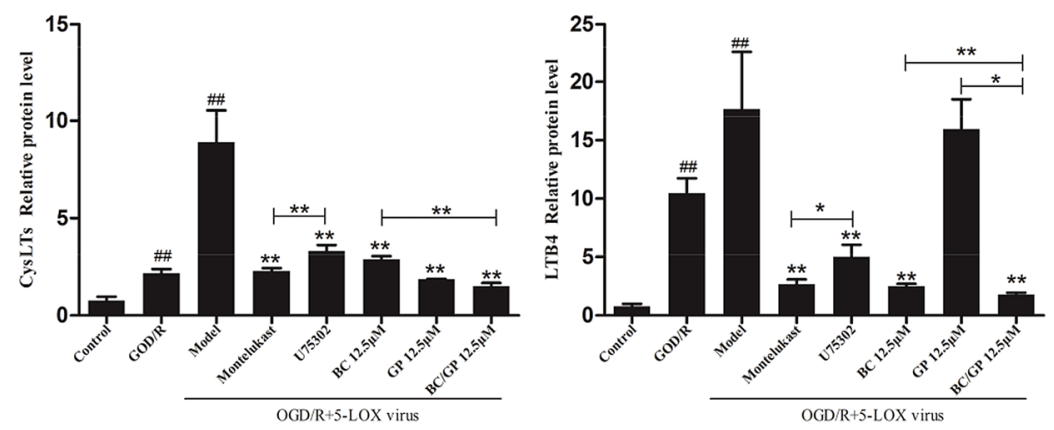

Fig. 10 Effects of BC/GP on the 5-LOX pathway. U75302 is an antagonist of LTB4. Montelukast is an antagonist of CysLTs. CysLT1 and CysLT2 are two receptors for CysLTs. BLT1 and BLT2 are two receptors for LTB4. LTA4H is a synthetase of LTB4. a Expression of the 5-LOX pathway was accessed using Western blots. b The related protein expression of the 5-LOX pathway was analyzed using qRTPCR. Each value indicates the mean $\pm \mathrm{SD}(\mathrm{n}=3)$. ${ }^{\# \#} \mathrm{p}<0.01 \mathrm{com}-$ pared to the control group, $* \mathrm{p}<0.05$ compared to the model group, $* * \mathrm{p}<0.01$ compared to model group

acute inflammation. It is induced primarily by the uptake of apoptotic cells or exposure to anti-inflammatory cytokines, including IL-10 and transforming growth factor- $\beta$ (TGF$\beta)[46,47]$. The general functional outcomes observed in acquired deactivation include inhibition of pro-inflammatory cytokine production, modification of inflammatory signaling pathways and increased expression of scavenger receptors thereby promoting debris clearance[47]. Following stimulation, microglia dynamically switch between M1 and M2 phenotypes resulting in neurotoxic and neuroprotective effects, respectively. Accordingly, a timely shift of microglial M1 to M2 phenotype has been regarded as a promising strategy for the management of neuroinflammation-related disorders [50]. Our research team established a model of 
BV2 microglia-activated inflammatory injury using in vitro LPS stimulation. We found that BC/GP inhibited the expression of NO, TNF- $\alpha$, and IL- 6 . BC/GP also increased the expression of IL-10 and TGF- $\beta$ to protect against neuronal injury after cerebral ischemia [51, 52]. Meanwhile, we discovered that BC/GP could inhibit the excessive activation of microglia through anti-inflammatory and neuroprotective effects and has protective effects on nerve injury following cerebral ischemia. Finally, BC/GP might be associated with inhibition of the expression of 5-LOX/CysLTs pathway [24]. In this study, we found that BC/GP inhibited both M1 polarization and M2 polarization of microglia. We stimulated BV2 cells three ways in the administration groups. (1) After BV2 microglia were transfected with the 5-LOX virus overexpression of 5-LOX led to microglia activation. (2) BC, GP, BC/GP (7:3) drug intervention caused microglia M1 to M2 phenotype. (3) Secondary damage of microglia caused by exposure to $\mathrm{OGD} / \mathrm{R}$ environment. In the model group, expression of the microglia M2 marker, CD206, was significantly increased without drug intervention. Therefore, we speculated that microglia were in the process of dynamic transformation from the M1 phenotype to the M2 phenotype. However, additional verification is needed.

Leukotrienes (LTs) are short-lived, potent pro-inflammatory lipid mediators expressed in macrophages, neutrophils, and mast cells [53]. Arachidonic acid stimulated the production of two groups of leukotrienes under the action of 5-LOX. LTB4 was produced due to the action of LTA4 hydrolase, and CysLTs were produced under the action of LTC4 synthase. Each group of leukotrienes acted through their specific receptors (BLTR and CysLTR, respectively) [54]. CysLTs play an essential role in the pathogenesis of a range of CNS diseases such as cerebral ischemia and brain trauma [55]. CysLTs are potent inflammatory mediators in ischemic stroke. The cysteinyl leukotriene receptor 2 (CysLTR2) has been shown in vitro to mediate microglial activation and indirectly induces ischemic neuronal injury. It has been reported that inhibiting the expression of the 5-LOX/CysLTs pathway could reduce the toxicity of neuroglial activation and exert anti-inflammatory effects in cerebrovascular disease [56-58].

LTB4 has been reported to activate and recruit leukocytes [59] and $T$ cells [60], which results in stimulating the production of cytokines and nuclear factor-kappaB (NF-кB) [61]. Excessive production of LTB4 results in robust production of chemokines and cytokines along with overwhelming neutrophil migration to the site of infection, where they release inflammatory mediators that cause tissue damage [62]. Thus, LTB4 is capable of maintaining the expression of inflammatory programs in monocytes and macrophages as well as prolonging neutrophil recruitment to the inflammatory foci [62]. Furthermore, when LTB4 binds to its receptor BLT1, it appears to impair the clearance of dead cells [63]. When apoptotic cells are not appropriately cleared, they become necrotic and secrete numerous toxic molecular components [64]. Inhibition of leukotriene B4 suppressed leukocyte infiltration after injury, thus reducing the expression of inflammatory factors TNF- $\alpha$, IL-6, and IL-1 $\beta$ [65]. LTB4 phosphorylates MAPKs and stimulates NF- $\kappa$ B-dependent inflammation via BLTR in cultured monocytes [61]. It has been shown that the plasma and brain levels of LTB4 increased simultaneously after cerebral ischemia, and elevation of LTB4 levels increased the volumes of the cerebral infarctions [53]. Under the ischemic conditions following a stroke, tissue glutathione (GSH) is rapidly depleted [66]. GSH is a critical component in the synthesis of CysLTs, and GSH deficiency inhibits their synthesis of CysLTs. Therefore, at the levels that could occur in the ischemic brain, the LTB4-mediated effects might become more pronounced.

In this study, we verified that BC and GP exhibited reasonable binding activity on LTA4H of LTB4 synthase through molecular docking. We established the OGD/R model for microglia along with overexpression of 5-LOX. In a series of experiments, we found that compared with the montelukast group, U75302 significantly reduced the expression of inflammatory factors TNF- $\alpha$, IL- $1 \beta$ and NF- $\kappa \mathrm{B}$ by OGD/R-treated microglia. Western blots and qRT-PCR results revealed that U75302 significantly inhibited the expression of 5-LOX. Therefore, we speculated that when 5-LOX was highly expressed, the 5-LOX/ LTB4 pathway might mediate a more severe inflammatory response. At the same time, U75302 reduced the expression of CD11b, a marker of M1-type microglia. However, the expression of CD206, a marker of M2-type microglia, was inhibited after drug administration. We speculated that when the microglia cells overexpressing 5-LOX were pretreated with U75302, montelukast, BC, GP, and BC/ GP for $4 \mathrm{~h}$ and then exposed to the OGD/R environment, the microglia cells were in a state of acquired deactivation and then changed via the process of dynamic transformation into the M1/M2 states. The results showed that BC/ GP significantly inhibited the expression of 5-LOX pathway proteins and inflammatory factors and inhibited the M1 polarization of microglia, which also had a synergistic effect.

In summary, $\mathrm{BC} / \mathrm{GP}$ might alleviate $\mathrm{OGD} / \mathrm{R}$ induced inflammatory damage of microglia through the 5-LOX/ LTB4 pathway. Therefore, the 5-LOX/LTB4 pathway blockade is expected to dampen inflammatory responses and restore tissue homeostasis during inflammation, which might provide a new therapeutic strategy for ischemic cerebrovascular disease.

Acknowledgements This work was supported by the National Nature Science Foundation of China (No. 81473385); Natural Science 
Foundation of Shaanxi Province (2018JM7111,2017JZ027); Discipline Innovation team of Shaanxi University of Chinese Medicine (2019-YL13). The authors would like to express their gratitude to EditSprings (https://www.editsprings.com/) for the expert linguistic services provided.

Author Contributions B.W. and M.L.: Conceptualization, Methodology, Software; H.L.: Data curation, Writing-Original draft preparation; H.Y.: Visualization, Investigation; Y.S.: Supervision; Y.W.: Software, Validation; J.L.: Writing-Reviewing and Editing.

Data Availability All data used to support the findings of this study are included within the article.

\section{Declarations}

Conflict of interest The authors have declared no any conflict of interest exists.

Open Access This article is licensed under a Creative Commons Attribution 4.0 International License, which permits use, sharing, adaptation, distribution and reproduction in any medium or format, as long as you give appropriate credit to the original author(s) and the source, provide a link to the Creative Commons licence, and indicate if changes were made. The images or other third party material in this article are included in the article's Creative Commons licence, unless indicated otherwise in a credit line to the material. If material is not included in the article's Creative Commons licence and your intended use is not permitted by statutory regulation or exceeds the permitted use, you will need to obtain permission directly from the copyright holder. To view a copy of this licence, visit http://creativecommons.org/licenses/by/4.0/.

\section{References}

1. Truelsen T, Mahonen M, Tolonen H, Asplund K, Bonita R, Vanuzzo D, Project WM (2003) Trends in stroke and coronary heart disease in the WHO MONICA Project. Stroke 34(6):13461352. https://doi.org/https://doi.org/10.1161/01.STR.0000069724. 36173.4D

2. Ding Y, Clark JC (2006) Cerebrovascular injury in stroke. Neurol Res 28(1):3-10. https://doi.org/10.1179/016164106X91799

3. Frangogiannis NG (2007) Chemokines in ischemia and reperfusion. Thromb Haemost 97(5):738-747

4. Owens T, Babcock AA, Millward JM, Toft-Hansen H (2005) Cytokine and chemokine inter-regulation in the inflamed or injured CNS. Brain Res Brain Res Rev 48(2):178-184. https:// doi.org/10.1016/j.brainresrev.2004.12.007

5. Iadecola C, Anrather J (2011) The immunology of stroke: from mechanisms to translation. Nat Med 17(7):796-808. https://doi. org/10.1038/nm.2399

6. Kaushal V, Schlichter LC (2008) Mechanisms of microgliamediated neurotoxicity in a new model of the stroke penumbra. $\mathrm{J}$ Neurosci 28(9):2221-2230. https://doi.org/10.1523/JNEUROSCI. 5643-07.2008

7. Zhou JM, Gu SS, Mei WH, Zhou J, Wang ZZ, Xiao W (2016) Ginkgolides and bilobalide protect BV2 microglia cells against OGD/reoxygenation injury by inhibiting TLR2/4 signaling pathways. Cell Stress Chaperones 21(6):1037-1053. https://doi.org/ 10.1007/s12192-016-0728-y

8. Sun P, Esteban G, Inokuchi T, Marco-Contelles J, Weksler BB, Romero IA, Couraud PO, Unzeta M, Sole M (2015) Protective effect of the multitarget compound DPH-4 on human SSAO/VAP1-expressing hCMEC/D3 cells under oxygen-glucose deprivation conditions: an in vitro experimental model of cerebral ischaemia. Br J Pharmacol 172(22):5390-5402. https://doi.org/10.1111/bph. 13328

9. Samuelsson B, Dahlen SE, Lindgren JA, Rouzer CA, Serhan CN (1987) Leukotrienes and lipoxins: structures, biosynthesis, and biological effects. Science 237(4819):1171-1176. https://doi.org/ $10.1126 /$ science. 2820055

10. Zhu L, Xu LZ, Zhao S, Shen ZF, Shen H, Zhan LB (2020) Protective effect of baicalin on the regulation of Treg/Th17 balance, gut microbiota and short-chain fatty acids in rats with ulcerative colitis. Appl Microbiol Biotechnol. https://doi.org/10.1007/ s00253-020-10527-w

11. Liao P, Li Y, Li M, Chen X, Yuan D, Tang M, Xu K (2020) Baicalin alleviates deoxynivalenol-induced intestinal inflammation and oxidative stress damage by inhibiting NF-kappaB and increasing mTOR signaling pathways in piglets. Food Chem Toxicol 140:111326. https://doi.org/10.1016/j.fct.2020.111326

12. Li R, Wang L (2019) Baicalin inhibits influenza virus A replication via activation of type I IFN signaling by reducing miR146a. Mol Med Rep 20(6):5041-5049. https://doi.org/10.3892/mmr. 2019.10743

13. Pang P, Zheng K, Wu S, Xu H, Deng L, Shi Y, Chen X (2018) Baicalin downregulates RLRs signaling pathway to control influenza A virus infection and improve the prognosis. Evid Based Complement Alternat Med 2018:4923062. https://doi.org/10.1155/2018/ 4923062

14. Jin J, Chen Y, Wang D, Ma L, Guo M, Zhou C, Dou J (2018) The inhibitory effect of sodium baicalin on oseltamivir-resistant influenza A virus via reduction of neuraminidase activity. Arch Pharm Res 41(6):664-676. https://doi.org/10.1007/s12272-018-1022-6

15. Tu L, Wu ZY, Yang XL, Zhang Q, Gu R, Wang Q, Tian T, Yao H, Qu X, Tian JY (2019) Neuroprotective effect and mechanism of baicalin on Parkinson's disease model induced by 6-OHDA. Neuropsychiatr Dis Treat 15:3615-3625. https://doi.org/10.2147/ NDT.S165931

16. Liu J, Zhang T, Wang Y, Si C, Wang X, Wang RT, Lv Z (2020) Baicalin ameliorates neuropathology in repeated cerebral ischemia-reperfusion injury model mice by remodeling the gut microbiota. Aging (Albany NY) 12(4):3791-3806. https://doi.org/ 10.18632/aging.102846

17. Dai J, Qiu YM, Ma ZW, Yan GF, Zhou J, Li SQ, Wu H, Jin YC, Zhang XH (2018) Neuroprotective effect of baicalin on focal cerebral ischemia in rats. Neural Regen Res 13(12):2129-2133. https://doi.org/10.4103/1673-5374.241464

18. Zheng WX, Cao XL, Wang F, Wang J, Ying TZ, Xiao W, Zhang Y, Xing H, Dong W, Xu SQ, Min ZL, Wu FJ, Hu XM (2015) Baicalin inhibiting cerebral ischemia/hypoxia-induced neuronal apoptosis via MRTF-A-mediated transactivity. Eur J Pharmacol 767:201-210. https://doi.org/10.1016/j.ejphar.2015.10.027

19. Koo HJ, Song YS, Kim HJ, Lee YH, Hong SM, Kim SJ, Kim BC, Jin C, Lim CJ, Park EH (2004) Antiinflammatory effects of genipin, an active principle of gardenia. Eur J Pharmacol 495(23):201-208. https://doi.org/10.1016/j.ejphar.2004.05.031

20. Zhao C, Zhang H, Li H, Lv C, Liu X, Li Z, Xin W, Wang Y, Zhang W (2017) Geniposide ameliorates cognitive deficits by attenuating the cholinergic defect and amyloidosis in middle-aged Alzheimer model mice. Neuropharmacology 116:18-29. https://doi.org/10. 1016/j.neuropharm.2016.12.002

21. Liu F, Wang Y, Yao W, Xue Y, Zhou J, Liu Z (2019) Geniposide attenuates neonatal mouse brain injury after hypoxic-ischemia involving the activation of PI3K/Akt signaling pathway. J Chem Neuroanat 102:101687. https://doi.org/10.1016/j.jchemneu.2019. 101687 
22. Wang J, Li D, Hou J, Lei H (2018) Protective effects of geniposide and ginsenoside $\operatorname{Rg} 1$ combination treatment on rats following cerebral ischemia are mediated via microglial microRNA1555p inhibition. Mol Med Rep 17(2):3186-3193. https://doi.org/10. 3892/mmr.2017.8221

23. 刘寒, 张欢欢, 康亚国, 侯建平, 李敏, 王斌 (2018) 黄芩苷与栃 子苷组合物对脑缺血损伤大鼠 5-LOX/CysLTs/CysLT 通路的 影响. 中成药 40 (05): 1020-1025

24. Wu J, Wang B, Li M, Shi YH, Wang C, Kang YG (2019) Network pharmacology identification of mechanisms of cerebral ischemia injury amelioration by Baicalin and Geniposide. Eur J Pharmacol 859:172484. https://doi.org/10.1016/j.ejphar.2019.172484

25. 刘寒, 张欢欢, 康亚国, 李敏, 张涓, 侯建平, 王斌 (2018) 黄芩 苷、㭛子苷配伍对脑缺血大鼠恢复期炎症因子的影响. 陕西 中医药大学学报 41 (03):75-81

26. Ru J, Li P, Wang J, Zhou W, Li B, Huang C, Li P, Guo Z, Tao W, Yang Y, Xu X, Li Y, Wang Y, Yang L (2014) TCMSP: a database of systems pharmacology for drug discovery from herbal medicines. J Cheminform 6:13. https://doi.org/10.1186/ 1758-2946-6-13

27. Trott O, Olson AJ (2010) AutoDock Vina: improving the speed and accuracy of docking with a new scoring function, efficient optimization, and multithreading. J Comput Chem 31(2):455-461. https://doi.org/10.1002/jcc.21334

28. Yao J, Hu R, Sun J, Lin B, Zhao L, Sha Y, Zhu B, You QD, Yan T, Guo QL (2014) Oroxylin A prevents inflammation-related tumor through down-regulation of inflammatory gene expression by inhibiting NF-kappaB signaling. Mol Carcinog 53(2):145-158. https://doi.org/10.1002/mc.21958

29. Hsin KY, Ghosh S, Kitano H (2013) Combining machine learning systems and multiple docking simulation packages to improve docking prediction reliability for network pharmacology. PLoS ONE 8(12):e83922. https://doi.org/10.1371/journal.pone.00839 22

30. Li HY, Hu J, Zhao S, Yuan ZY, Wan HJ, Lei F, Ding Y, Xing DM, Du LJ (2012) Comparative study of the effect of baicalin and its natural analogs on neurons with oxygen and glucose deprivation involving innate immune reaction of TLR2/TNFalpha. J Biomed Biotechnol 2012:267890. https://doi.org/10.1155/2012/267890

31. Yuan Y, Zheng Z (2019) Geniposide protects PC-12 cells against oxygen and glucose deprivation-induced injury by up-regulation of long-noncoding RNA H19. Life Sci 216:176-182. https://doi. org/10.1016/j.lfs.2018.11.047

32. Wang P, Cao Y, Yu J, Liu R, Bai B, Qi H, Zhang Q, Guo W, Zhu $\mathrm{H}, \mathrm{Qu} \mathrm{L}$ (2016) Baicalin alleviates ischemia-induced memory impairment by inhibiting the phosphorylation of CaMKII in hippocampus. Brain Res 1642:95-103. https://doi.org/10.1016/j.brain res.2016.03.019

33. 李敏, 王斌, 曹慧, 武璞, 沈甜, 宋亚刚, 翟小虎, 侯建平 (2017) 基于AQP-4、P-gp黄芩苷、秨子苷配伍对缺血/再灌注损伤大 鼠血脑屏障保护机制研究. 中国药理学通报 33 (03):443-444

34. 李敏, 曹慧, 王斌, 沈甜, 宋亚刚, 翟小虎 (2017) 基于AQP-4 、GFAP的黄芩苷、枚子苷配伍抗脑缺血大鼠神经功能损伤 的㸴究. 中药药理与临床 33(02):56-59

35. 刘阿萍, 李敏, 王斌, 曹慧, 李阳, 周福盈 (2016) 黄芩苷和桅子 苷配伍对大鼠脑缺血再灌注损伤的作用研究. 中药药理与临 床 32(01):46-48

36. 李敏, 王斌, 唐志书, 侯建平, 李吴睿 (2012) 黄芩苷、秨子苷对 大鼠脑缺血保护作用的机制. 中药药理与临床 28(03):34-36

37. Sharman MJ, Verdile G, Kirubakaran S, Parenti C, Singh A, Watt G, Karl T, Chang D, Li CG, Munch G (2019) Targeting inflammatory pathways in Alzheimer's disease: a focus on natural products and phytomedicines. CNS Drugs 33(5):457-480. https://doi.org/ 10.1007/s40263-019-00619-1

38. Ren M, Guo Y, Wei X, Yan S, Qin Y, Zhang X, Jiang F, Lou H (2018) TREM2 overexpression attenuates neuroinflammation and protects dopaminergic neurons in experimental models of Parkinson's disease. Exp Neurol 302:205-213. https://doi.org/10.1016/j. expneurol.2018.01.016

39. Jin X, Liu MY, Zhang DF, Zhong X, Du K, Qian P, Gao H, Wei MJ (2019) Natural products as a potential modulator of microglial polarization in neurodegenerative diseases. Pharmacol Res 145:104253. https://doi.org/10.1016/j.phrs.2019.104253

40. Gehrmann J, Matsumoto Y, Kreutzberg GW (1995) Microglia: intrinsic immuneffector cell of the brain. Brain Res Brain Res Rev 20(3):269-287. https://doi.org/10.1016/0165-0173(94)00015-h

41. Willis CL (2011) Glia-induced reversible disruption of bloodbrain barrier integrity and neuropathological response of the neurovascular unit. Toxicol Pathol 39(1):172-185. https://doi.org/10. 1177/0192623310385830

42. Smith JA, Das A, Ray SK, Banik NL (2012) Role of pro-inflammatory cytokines released from microglia in neurodegenerative diseases. Brain Res Bull 87(1):10-20. https://doi.org/10.1016/j. brainresbull.2011.10.004

43. Vilhardt F (2005) Microglia: phagocyte and glia cell. Int J Biochem Cell Biol 37(1):17-21. https://doi.org/10.1016/j.biocel. 2004.06.010

44. Brown GC, Neher JJ (2010) Inflammatory neurodegeneration and mechanisms of microglial killing of neurons. Mol Neurobiol 41(2-3):242-247. https://doi.org/10.1007/s12035-010-8105-9

45. Marchetti B, Pluchino S (2013) Wnt your brain be inflamed? Yes, it Wnt! Trends Mol Med 19(3):144-156. https://doi.org/ 10.1016/j.molmed.2012.12.001

46. Colton CA (2009) Heterogeneity of microglial activation in the innate immune response in the brain. J Neuroimmune Pharmacol 4(4):399-418. https://doi.org/10.1007/s11481-009-9164-4

47. Colton C, Wilcock DM (2010) Assessing activation states in microglia. CNS Neurol Disord Drug Targets 9(2):174-191. https://doi.org/10.2174/187152710791012053

48. Loane DJ, Byrnes KR (2010) Role of microglia in neurotrauma. Neurotherapeutics 7(4):366-377. https://doi.org/10.1016/j.nurt. 2010.07.002

49. Durafourt BA, Moore CS, Zammit DA, Johnson TA, Zaguia F, Guiot MC, Bar-Or A, Antel JP (2012) Comparison of polarization properties of human adult microglia and blood-derived macrophages. Glia 60(5):717-727. https://doi.org/10.1002/glia. 22298

50. Tang Y, Le W (2016) Differential roles of M1 and M2 microglia in neurodegenerative diseases. Mol Neurobiol 53(2):1181-1194. https://doi.org/10.1007/s12035-014-9070-5

51. 沈甜, 张怡, 强朝阳, 张欢欢, 刘寒, 李敏, 王斌 (2017) 黄芩苷栃 子苷配伍对脂多糖致BV2小胶质细胞激活损伤的影响. 世界最 新医学信息文摘 17(45):148-150

52. 高原雪, 沈甜, 何林, 李豪, 李敏, 王斌 (2019) 黄芩苷、柧子苷 及其配伍对小胶质细胞增殖及激活后炎性因子影响. 现代中 医药 39(03): 106-109

53. Chan SJ, Ng MPE, Zhao H, Ng GJL, De Foo C, Wong PT, Seet RCS (2019) Early and sustained increases in leukotriene B4 levels are associated with poor clinical outcome in ischemic stroke patients. Neurotherapeutics. https://doi.org/10.1007/ s13311-019-00787-4

54. De Caterina R, Zampolli A (2004) From asthma to atherosclerosis-5-lipoxygenase, leukotrienes, and inflammation. N Engl J Med 350(1):4-7. https://doi.org/10.1056/NEJMp038190

55. Colazzo F, Gelosa P, Tremoli E, Sironi L, Castiglioni L (2017) Role of the cysteinyl leukotrienes in the pathogenesis and progression of cardiovascular diseases. Mediators Inflamm 2017:2432958. https://doi.org/10.1155/2017/2432958

56. Shi QJ, Wang H, Liu ZX, Fang SH, Song XM, Lu YB, Zhang WP, Sa XY, Ying HZ, Wei EQ (2015) HAMI 3379, a CysLT2R antagonist, dose- and time-dependently attenuates brain injury and inhibits microglial inflammation after focal cerebral ischemia 
in rats. Neuroscience 291:53-69. https://doi.org/10.1016/j.neuro science.2015.02.002

57. Yu SY, Zhang XY, Wang XR, Xu DM, Chen L, Zhang LH, Fang SH, Lu YB, Zhang WP, Wei EQ (2014) Cysteinyl leukotriene receptor 1 mediates LTD4-induced activation of mouse microglial cells in vitro. Acta Pharmacol Sin 35(1):33-40. https://doi.org/10. 1038/aps.2013.130

58. Zhang XY, Chen L, Yang Y, Xu DM, Zhang SR, Li CT, Zheng W, Yu SY, Wei EQ, Zhang LH (2014) Regulation of rotenoneinduced microglial activation by 5 -lipoxygenase and cysteinyl leukotriene receptor 1. Front Mol Neurosci 1572:59-71. https:// doi.org/10.1016/j.brainres.2014.05.026

59. Gimbrone MA Jr, Brock AF, Schafer AI (1984) Leukotriene B4 stimulates polymorphonuclear leukocyte adhesion to cultured vascular endothelial cells. J Clin Invest 74(4):1552-1555. https://doi. org/10.1172/JCI111570

60. Goodarzi K, Goodarzi M, Tager AM, Luster AD, von Andrian UH (2003) Leukotriene B4 and BLT1 control cytotoxic effector T cell recruitment to inflamed tissues. Nat Immunol 4(10):965-973. https://doi.org/10.1038/ni972

61. Sanchez-Galan E, Gomez-Hernandez A, Vidal C, Martin-Ventura JL, Blanco-Colio LM, Munoz-Garcia B, Ortega L, Egido J, Tunon J (2009) Leukotriene B4 enhances the activity of nuclear factorkappaB pathway through BLT1 and BLT2 receptors in atherosclerosis. Cardiovasc Res 81(1):216-225. https://doi.org/10.1093/cvr/ cvn277

62. Brandt SL, Serezani CH (2017) Too much of a good thing: how modulating LTB4 actions restore host defense in homeostasis or disease. Semin Immunol 33:37-43. https://doi.org/10.1016/j. smim.2017.08.006

63. Kojima Y, Volkmer JP, McKenna K, Civelek M, Lusis AJ, Miller CL, Direnzo D, Nanda V, Ye J, Connolly AJ, Schadt EE, Quertermous T, Betancur P, Maegdefessel L, Matic LP, Hedin U, Weissman IL, Leeper NJ (2016) CD47-blocking antibodies restore phagocytosis and prevent atherosclerosis. Nature 536(7614):8690. https://doi.org/10.1038/nature18935

64. Piccinini AM, Midwood KS (2010) DAMPening inflammation by modulating TLR signalling. Mediators Inflamm. https://doi.org/ $10.1155 / 2010 / 672395$

65. Saiwai H, Ohkawa Y, Yamada H, Kumamaru H, Harada A, Okano H, Yokomizo T, Iwamoto Y, Okada S (2010) The LTB4-BLT1 axis mediates neutrophil infiltration and secondary injury in experimental spinal cord injury. Am J Pathol 176(5):2352-2366. https://doi.org/10.2353/ajpath.2010.090839

66. Salemi G, Gueli MC, D’Amelio M, Saia V, Mangiapane P, Aridon P, Ragonese P, Lupo I (2009) Blood levels of homocysteine, cysteine, glutathione, folic acid, and vitamin B12 in the acute phase of atherothrombotic stroke. Neurol Sci 30(4):361-364. https://doi.org/10.1007/s10072-009-0090-2

Publisher's Note Springer Nature remains neutral with regard to jurisdictional claims in published maps and institutional affiliations. 